Niepodległość. Idee, fakty, perspektywy. W 100. rocznicę odzyskania niepodległości przez Polskę, red. P. Krokosz, S. Romański-Cebula, Kraków 20I9, S. I2I-I37

DOI: http://dx.doi.org/Io.15633/9788374388085.07

JAKUB KRZYSZTONEK

Uniwersytet Papieski Jana Pawła II w Krakowie

\title{
Roman Dmowski i sprawa Polski na konferencji wersalskiej
}

\section{Abstrakt}

Artykuł dotyczy aspektów dyplomatycznej oraz organizacyjnej działalności zarówno w wymiarze formalnym, jak i zakulisowym - Romana Dmowskiego, współtwórcy Narodowej Demokracji i nowoczesnej myśli nacjonalistycznej. Dmowski, stojący na czele Komitetu Narodowego Polskiego, był oficjalnym przedstawicielem rządu polskiego podczas konferencji pokojowej w Paryżu w latach I9I9-I920, która ustalała europejski ład po zakończeniu I wojny światowej. W pierwszej części artykułu przedstawiono krótki rys biograficzny głównego bohatera oraz sytuację geopolityczną schyłku I9ı8 roku widzianą z perspektywy członków Komitetu Narodowego Polskiego. Zasadniczy przekaz koncentruje się na działalności Dmowskiego od rozpoczęcia konferencji paryskiej (I8 stycznia I9I9 roku) aż po dzień podpisania przez delegację polską dokumentu przywracającego formalnie państwo polskie na mapę Europy (28 czerwca I9I9 roku). W artykule poruszono również problem związany z wytyczeniem granicy wschodniej w kontekście sporu międzynarodowego o statut Galicji Wschodniej.

Stowa kluczowe

Roman Dmowski, Narodowa Demokracja, Komitet Narodowy Polski, konferencja wersalska, II Rzeczpospolita, Galicja Wschodnia

\section{Abstract}

Roman Dmowski and the issue of Poland at the conference of Versailles.

The article concerns aspects of a diplomatic and organizational activity - both in formal and back-stage dimension - of Roman Dmowski, the co-author of National Democracy and a modern nationalist thought. Dmowski, standing 
at the head of Polish National Committee, was an official representative of Polish government during the peace conference in Paris in I9I9-I920 which provided European order after the end of the First World War. The short biographical trait of Dmowski is presented as well as the geopolitical situation of the decline I9I8 seen from the perspective of members of National Polish Committee. The essential transfer of the article is concentrated on the activity of Dmowski from the beginning of the Parisian conference (I8 January, I9I9) till the day of signing the document formally restoring Poland on the map of Europe (28 June, I9I9) by the Polish delegation. The problem connected with the delimitation of eastern border in the context of the international dispute over the statute of Eastern Galicia is brought up.

\section{Keywords}

Roman Dmowski, National Democracy, Polish National Committee, the conference of Versailles, the Second Polish Republic, Eastern Galicia

„Runął jak dąb prastary, a dusza załopotała wiecznymi skrzydłami w nieznaną dla nas wielką dal... Oczyma wiary widzimy ten lot i drogę wieczną. Naprzeciw wyszły duchy z przeszłości naszej z Chrobrym na czele i witały swego wielkiego rodaka. [...] Puść Panie sługę Swego Romana do przybytków świętej szczęśliwości, sługę plemienia naszego...”. Te doniosłe słowa znalazły się w zakończeniu mowy żałobnej wygłoszonej przez ks. prałata Marcelego Nowakowskiego w archikatedrze św. Jana w Warszawie podczas uroczystości pogrzebowych Dmowskiego, na które jak się szacuje, tylko w samej stolicy 7 stycznia I939 roku przybył tłum liczący około ıoo tys. żałobników². Symboliczny w tym kontekście wydaje się fakt, iż Dmowski przechodził do historii niemal równocześnie z ładem wersalskim, którego był przecież jednym z ważnych twórców. Spróbujmy zatem przybliżyć tę postać i jej najważniejsze osiągnięcia dla sprawy polskiej na arenie międzynarodowej w czasie pamiętnej konferencji.

I Roman Dmowski 1864-1939. Życiorys - wspomnienia - zbiór fotografii, oprac. Feliks Fikus, Poznań I939, s. 9o.

2 K. Kawalec, Roman Dmowski, Poznań 20ı6, s. 478; zob. też Roman Dmowski 1964-1939. Życiorys..., dz. cyt., s. 88. 
Roman Dmowski urodził się 9 sierpnia I864 roku w podwarszawskim wówczas Kamionku w rodzinie brukarza Walentego i Józefy z Lenarskich. Zinstytucjonalizowaną naukę rozpoczął młody Roman w I87i roku w szkole elementarnej na Pradze, zaś od roku i875 uczęszczał do III gimnazjum w Warszawie. W wieku dwudziestu dwóch lat podjął studia na Cesarskim Uniwersytecie Warszawskim, aby w i89I roku uzyskać stopień naukowy odpowiadający tytułowi doktora nauk przyrodniczych. Wielki potencjał intelektualny Dmowskiego został rychło doceniony, co wiązało się m.in. z otrzymaną przezeń propozycją przygotowania habilitacji w Uniwersytecie Jagiellońskim. Inne jednak miał już wtedy bohater naszego artykułu plany i zapatrywania na otaczający go świat. W poczuciu patriotycznego obowiązku zrezygnował bowiem z możliwości robienia kariery naukowej na rzecz mozolnej pozytywistycznej pracy u podstaw wśród rodaków na ziemi ojczystej i poza jej dawnymi granicami. Publicystyka polityczna stała się dlań wkrótce najważniejszym narzędziem oddziaływania na wyraźnie rozwarstwione społeczeństwo33.

Można by w tym miejscu długo wymieniać zasługi Dmowskiego w dziele skutecznego budzenia i uświadamiania narodu polskiego, począwszy od chwili utworzenia Ligi Narodowej w I893 roku, poprzez niwelowanie skutków rewolucji proletariackiej roku I905, aż do momentu wybuchu I wojny światowej - lecz nie to jest przecież istotą rzeczonej rozprawy. Wspomnieć jednak należy, iż był on współtwórcą i niekwestionowanym liderem nowoczesnego nacjonalizmu polskiego, którego polityczną emanacją stała się Narodowa Demokracja - partia mająca swoje zaplecze i szerokie poparcie społeczne wśród Polaków na obszarze wszystkich trzech państw zaborczych, a później w odrodzonej Drugiej Rzeczypospolitej.

Zanim jednak doszło do rzeczywistego powrotu Polski na europejską mapę, wiele musiało się wydarzyć. Niemniej trudno sobie dziś wyobrazić wskrzeszenie tej państwowości bez uprzedniej realizacji autorskiego projektu Romana Dmowskiego, jakim bez wątpienia był Komitet Narodowy Polski powołany formalnie do życia I5 sierpnia

3 R. Wapiński, Roman Dmowski, Lublin I988, s. I5-5 I. 
I9I7 roku w Lozannie4. KNP był w pewnym sensie kontynuacją istniejącego od listopada I9I4 roku w Warszawie, a mającego swoje przedstawicielstwo w Petersburgu, podmiotu politycznego o tej samej nazwie skupiającego endeków, realistów i bezpartyjnych, widzących odbudowę przyszłego państwa polskiego u boku dynastii Romanowów. Frontowe porażki Rosjan i wystąpienia rewolucyjne kazały jednak Dmowskiemu skorygować nieco jego pierwotne plany. Pozorowana dotychczas gra kartą prorosyjską została we właściwym momencie zreorientowana całkowicie na opcję profrancuską5. W kontekście tych wydarzeń lider endecji I2 sierpnia I9I7 roku przygotował specjalny komunikat dla rodaków przebywających w kraju:

Celem polityki polskiej w obecnej wojnie jest osiągnięcie niepodległego państwa polskiego w warunkach zapewniających mu całkowitą niezależność od sąsiadów i rolę mocarstwową w Europie. Tym warunkom może odpowiedzieć tylko państwo polskie zbudowane na obszarze trzech zaborów, oparte o Bałtyk, z granicą o tyle na wschód posuniętą, żeby mogło posiadać 30-40 milionów ludności. Po przewrocie w Rosji, przeszkody z jej strony do utworzenia takiego państwa nie zapowiadają się groźnie, natomiast ze strony Niemiec mogą być one usunięte, tylko przez wielkie i decydujące zwycięstwo aliantów nad państwami centralnymi ${ }^{6}$.

Działający w latach I9I7-I9I9 Komitet Narodowy Polski był pierwszą oficjalnie uznaną przez kraje Ententy instytucją reprezentującą na arenie międzynarodowej interesy odradzającego się państwa polskiego. Posiadał przedstawicielstwa akredytowane przy rządach państw sprzymierzonych. Zakres jego działalności wykraczał daleko poza struktury formalne. Wykorzystując rozmaite kanały informacyjne, prowadził de facto trudną sztukę dyplomacji, pełniąc zarówno funkcję Ministra

4 Protokót z posiedzenia Komitetu Narodowego Polskiego w Lozannie 15-16 VIII 1917 r., w: Komitet Narodowy Polski: protokoły posiedzeń 1917-1919, oprac. M. Jabłonowski, D. Cisowska-Hydzik, Warszawa 2007, s. 5 I.

5 J. Buszko, Od niewoli do niepodległości (1864-1918), t. 8: Wielka Historia Polski, Kraków 2000, s. 349, 37I; J. Pajewski, Odbudowa państwa polskiego: 1914-1918, Warszawa 1985, s. 61-62.

6 Tekst komunikatu do kraju zaproponowany przez R. Dmowskiego i uchwalony podczas narad KNP w Lozannie 12 VIII 1917 r., w: Komitet Narodowy Polski: protokoły posiedzeń 1917-1919..., dz. cyt., s. 36-37. 
Spraw Zagranicznych, jak i Ministra Spraw Wojskowych. Jedną z jego ważnych misji była organizacja ochotniczej armii polskiej nad Sekwaną. W skład Komitetu wchodzili przede wszystkim przedstawiciele Stronnictwa Demokratyczno-Narodowego - oprócz Dmowskiego m.in. Marian Seyda, Maurycy hr. Zamoyski, Stanisław Kozicki czy choćby Jan Jordan Rozwadowski. Swoich wpływowych reprezentantów miało również Stronnictwo Polityki Realnej - mowa tutaj m.in. o takich osobistościach jak Erazm Piltz i Konstanty hr. Skirmunt. Członkiem KNP był również rozpoznawalny na światowych salonach pianista Ignacy Jan Paderewski. Natomiast od stycznia I9I9 roku na mocy porozumienia skład Komitetu został poszerzony o przedstawicieli innych ugrupowań politycznych - głównie lewicowych z nadania Naczelnika Państwa Józefa Piłsudskiego. Pomimo pewnych perturbacji nie wpłynęło to jednak zasadniczo na zmianę prowadzonej przez endeków polityki tego gremium ${ }^{7}$.

Tymczasem I wojna światowa dobiegała końca. Niemieckie sukcesy na froncie wschodnim na niewiele się zdały wobec załamania ich ofensywy na Zachodzie Europy w drugiej połowie I9I8 roku. Geopolityczne kalkulacje Dmowskiego okazały się zatem wyjątkowo trafne. Nic więc dziwnego, że już I3 listopada, a więc dwa dni po podpisaniu rozejmu w Compiegne, w nadesłanej do KNP nocie rząd francuski uznał Komitet za Gouvernement de fait w zakresie polityki zagranicznej, kierowania armią polską i opieki cywilnej nad Polakami za granicą. Francuzi poinformowali równocześnie o zbliżającej się konferencji pokojowej aliantów, na którą oficjalne zaproszenie dla KNP miało wpłynąć zaraz po formalnej akceptacji pozostałych państw koalicji ${ }^{8}$.

Kolejne tygodnie upłynęły Komitetowi pod znakiem wytężonej pracy i komunikowania się zarówno z krajem, gdzie rzeczywistą władzę przejął Piłsudski, jak i z przedstawicielami mocarstw, które szykowały się do ustanowienia nowego powojennego ładu. W połowie stycznia

7 J. Zamoyski, Powrót na mapę. Polski Komitet Narodowy w Paryżu 1914-1919, Warszawa I99I, s. 60-67; Komitet Narodowy Polski: protokoły posiedzeń 19171919..., dz. cyt., s. 5-17.

8 Protokót z posiedzenia KNP w dniu 13 XI 1918 r., w: Komitet Narodowy Polski: protokoły posiedzeń 1917-1919..., dz. cyt., S. 595. 
I9I9 roku na mocy uprzednio przygotowanego porozumienia KNP został uznany przez Józefa Piłsudskiego za oficjalną reprezentacje państwa polskiego na konferencji pokojowej w Paryżu. Delegatami pełnomocnymi ze strony Polski zostali prezes Roman Dmowski i świeżo nominowany premier Ignacy Paderewski .

W niedzielę I8 stycznia I9I9 roku rozpoczęła się konferencja paryska. Na inauguracyjne posiedzenie przybyło sześćdziesięciu ośmiu oficjalnych delegatów z dwudziestu siedmiu państw, ale decydujący głos w kwestii ustanawiania nowego porządku światowego mieli mieć przedstawiciele pięciu zwycięskich mocarstw, zasiadający w powołanej na potrzeby obrad Radzie Najwyższej. Tak oto głównymi sędziami w sprawie wytyczenia przyszłych granic państw europejskich, w tym Polski, stali się prezydent USA Woodrow Wilson oraz premierzy: Francji-Georges Clemenceau, Wielkiej Brytanii - David Lloyd George i Włoch - Vittorio Orlando ${ }^{\text {Io }}$.

Nie minęły dwa tygodnie od inauguracji prac konferencji, a 29 stycznia przed oblicze Rady Dziesięciu w trybie pilnym został wezwany Roman Dmowski. Pozbawiony wsparcia ze strony Paderewskiego, który był wówczas nieobecny w Paryżu, lider endecji musiał zdać - jak się później okazało - najważniejszy egzamin w swoim politycznym życiu. Leżący na szali w tym pamiętnym dniu osobisty autorytet Dmowskiego zdawał się jednak być niczym wobec powagi sprawy, którą przyszło mu referować.

Wystąpienie Dmowskiego prowadzone równolegle po francusku i angielsku składało się z dwóch części przedzielonych przerwą obiadową, a trwało łącznie około pięciu godzin. Zasadniczym tematem jego wywodów - prowadzonych początkowo bez żadnych notatek i map był całokształt kwestii polskiej. Arystotelesowska logika jego narracji,

9 Projekt układu KNP $z$ delegacja J. Piłsudskiego przedstawiony na posiedzeniu Komitetu 14 I 1919 r., w: Komitet Narodowy Polski: protokoły posiedzeń 1917-1919..., dz. cyt., s. 649-650; zob. też J. Zamoyski, Powrót na mapę..., dz. cyt., s. I28-ı29.

Io H. Batowski, Między dwiema wojnami 1919-1939. Zarys historii dyplomatycznej, Kraków 200I, s. 27-30; S. Kozicki, Pamiętnik Stanistawa Kozickiego 1876-1939, t. 3, cz. 6 [Rękopis], Biblioteka Jagiellońska, sygn. rkp. 9784 III, k. 59-60; „Gazeta Warszawska” ıوı9 nr ı8, s. 6. 
bogactwo argumentów i empiryczna wręcz znajomość opisywanego przedmiotu w połączeniu z umiejętnością celnej riposty w odpowiedzi na podchwytliwe pytania, zadawane przez nie zawsze życzliwych mu członków Rady, po latach docenił w swojej książce nawet jego wielki rywal, przez wielu postrzegany jako stronnik niemieckich i żydowskich interesów w Wersalu - brytyjski hrabia Lloyd George ${ }^{\text {II }}$.

Postulowane na posiedzeniu przez Dmowskiego terytorium Polski było niemal kalką wcześniejszych dokumentów składanych na ręce przedstawicieli Ententy jeszcze przed zakończeniem wojny. Mowa tutaj przede wszystkim o dwóch kluczowych memoriałach. Pierwszy z nich, o zagadnieniach Europy Środkowej i Wschodniej, był wręczony przez Dmowskiego ministrowi spraw zagranicznych Zjednoczonego Królestwa Arturowi Balfourowi w lipcu I9I7 roku, zaś drugi, o projektowanych granicach Polski, został dostarczony przez lidera endeków do Waszyngtonu prezydentowi Stanów Zjednoczonych Woodrowowi Wilsonowi w październiku ıgı8 roku ${ }^{12}$.

Wobec powyższego na pierwszy plan posiedzenia wysuwała się kwestia granicy z Niemcami - tym bardziej istotna w kontekście trwającego wówczas powstania w Wielkopolsce. Delegacja polska podnosiła w tym przypadku argument etniczny i postulowała przesunięcie granicy na zachód wobec rozwoju żywiołu polskiego poza linię graniczną z roku I772. Szczególna trudność wiązała się jednak z kwestią przyszłej przynależności państwowej Prus Wschodnich. Dmowski prowadził w tej sprawie umiejętny dyskurs mówiąc: „oczywiście, państwo polskie nie chce opierać się na gwałcie i nie chce pod żadnym pozorem wcielania wysepki Królewca, ale jeśli pod pretekstem przyłączenia Niemców z Królewca do Niemiec pozbawiono by Polskę do-

I I Zob. K. Kawalec, Roman Dmowski, dz. cyt., s. 329; S. Kozicki, Sprawa granic Polski na konferencji pokojowej w Paryżu, Warszawa I92 I, s. 45-46, 58, 6I-62; zob. też R. Wapiński, Roman Dmowski, dz. cyt., s. 269-270; R. Dmowski, Polityka polska i odbudowanie państwa, Warszawa I926, s. 362-364; D. Lloyd George, Prawda o traktacie wersalskim, t. I, Warszawa I939, s. 28I.

I2 Akty i dokumenty dotyczace sprawy granic Polski na Konferencji Pokojowej w Paryźu 1918-1919, cz. I: Program terytorialny delegacji, zebr. i wyd. przez Sekretariat Generalny Delegacji Polskiej (dalej: ADKPP:I), Paryż I920, s. 2I-7I. 
stępu do morza, niesprawiedliwość byłaby większa niż w przypadku przyłączenia Królewca do Polski. Wielu ludziom może się wydawać, że Polska jest przyzwyczajona do aktów niesprawiedliwości, że może znieść jeszcze i inne, lecz jeśli już niesprawiedliwości musi stać się zadość, to czyż nie lepiej będzie, jeśli skierowana ona będzie przeciwko Niemcom, którzy poprzez całe wieki narzucali ją swym sąsiadom[?]”з.

Inną nieco retorykę prowadził przywódca Narodowej Demokracji, jeśli chodzi o wytyczenie wschodniej granicy Rzeczypospolitej, choć i tutaj trwające wtenczas oblężenie Lwowa i militarne zmagania z Ukraińcami o Galicję Wschodnią nie ułatwiały mu bynajmniej zadania. Niemniej w tym przypadku zasadnie wskazywał, iż historycznej granicy z Cesarstwem Rosyjskim z roku I772 odtworzyć się nie da wobec rozwoju na tych rubieżach antypolskiego i proniemieckiego w swojej istocie żywiołu ukraińskiego, a także litewskiego. Działanie to było zresztą zgodne z inkorporacyjną koncepcją endecji, która w tym aspekcie stała w kontrze do federalistycznych wizji Piłsudskiego. Dmowski na posiedzeniu Rady mówił wprost:

Jeśli Liga Narodów przyjęłaby jako członków takie państwa jak Litwa i Ukraina, to przyjęłaby na swoje łono nie państwa silne, ale zorganizowaną anarchię. Cały świat jest przeto zainteresowany, aby na wschodzie Europy mieć państwo dobrze zorganizowane, zdolne do zapewnienia porządku i utrzymania pokoju. W tych warunkach nie wydaje się, aby można było uznać Ukrainę jako państwo samodzielne, niezależne. Co do Litwy, to jeśli można przyjąć możliwość uznania jej autonomii - i rząd polski ma nadzieję, że tak będzie - to państwo liczące $3 \mathrm{mln}$ ludzi powinno być połączone z Polską, gdyż nie jest ono zdolne istnieć samo. [...] Rosja [zaś] jeszcze długo będzie państwem najbardziej nieszczęśliwym na świecie, gdzie czarny despotyzm może znaleźć następcę w postaci czerwonego despotyzmu ${ }^{\mathrm{I}}$.

Po wysłuchaniu polskiego delegata Rada Najwyższa powołała do życia Komisję ds. polskich pod przewodnictwem Francuza Jules'a Cambona i wysłała misję specjalną nad Wisłę celem zbadania panującej

I3 Notatki sekretarza z wystapienia R. Dmowskiego na posiedzeniu Rady Najwyższej Sprzymierzonych w dniu 29 I 1919 r., w: Komitet Narodowy Polski: protokoty posiedzeń 1917-1919..., s. 685 .

I4 Zob. Notatki sekretarza z wystapienia R. Dmowskiego..., dz. cyt., s. 686-687. 
wówczas sytuacji ${ }^{15}$. Tymczasem okres lutego i marca I9I9 roku był dla Dmowskiego i sprawy polskiej bez wątpienia czasem dobrej politycznej koniunktury. Prezes KNP dzięki swojemu osobistemu zaangażowaniu i prywatnym kontaktom zdołał przekonać do projektu granic członków międzynarodowego zespołu ekspertów. Duże znaczenie dla terytorialnego kształtu Rzeczypospolitej miały również oficjalnie składane przez Dmowskiego dokumenty, w tym szczególnie podpisana przez niego nota Delegacji Polskiej w sprawie granicy zachodniej z 28 lutego skierowana do przewodniczącego Cambona ${ }^{\mathrm{I} 6}$.

W konsekwencji szeregu dyplomatycznych zabiegów lider endecji doprowadził do przyjęcia przez Komisję dość korzystnego dla interesu Polski projektu granicy. I5 marca zatwierdził go Centralny Komitet Terytorialny. Prawie wszystkie postulaty polskiej delegacji zostały w nim uwzględnione. Jedynie na Mazurach miał się odbyć plebiscyt ${ }^{17}$. Jak się jednak później okazało zmieniające się okoliczności geopolityczne i wpływ czynników zewnętrznych na pracę Kongresu ograniczyły ostateczny zasięg terytorialny państwa polskiego na Zachodzie ${ }^{\mathrm{I}}$. Napisze po latach z poczuciem pewnego niedosytu Dmowski:

Komisja zachowała dużą rezerwę w stosunku do naszych żądań, wykreśliła dla państwa bardzo granicę trudną. Jednakże przyznawała nam nasz Śląsk Górny i Gdańsk. Nie uważałem tej decyzji za nasz triumf, jakkolwiek Polacy w Paryżu byli na ogół uradowani. Jeden z nich wyszukał i przysłał mi z powinszowaniami butelkę gdańskiej wódki, tej samej, którą pił sędzia w Panu Tadeuszu. Odpowiedziałem mu, że stawiam ją na półkę i że wypijemy ją razem wtedy, kiedy Gdańsk naprawdę do nas będzie należał. Lloyd George zaczynał już na dobre gospodarzyć na konferencji. Wódki tej nigdy nie skosztowałem [... $]^{\text {19 }}$.

Od końca marca do początku maja I9I9 roku pogarszała się atmosfera wokół kwestii polskiej, co można obiektywnie interpretować jako skutek zmian, jakie dokonały się w obrębie delegacji brytyjskiej. Sam

I5 Zob. S. Kozicki, Sprawa granic Polski..., dz. cyt., s. 62-63.

I6 ADKPP:I, s. Io9-I23. Zob. też K. Kawalec, Roman Dmowski, dz. cyt., s. 333334; S. Kozicki, Pamiętnik Stanisława Kozickiego..., k. I I7.

I7 Zob. K. Kawalec, Roman Dmowski, dz. cyt, s. 334.

I8 Zob. R. Wapiński, Roman Dmowski, dz. cyt., s. 273-275.

I9 Zob. R. Dmowski, Polityka polska, dz. cyt., s. 372-373. 
Dmowski tłumaczył tę nową sytuację wpływami środowisk żydowskich na linię polityki prowadzonej przez przedstawicieli Zjednoczonego Królestwa w Paryżu. Zdaniem przedstawicieli endecji szczególnie negatywną rolę odegrał w tym kontekście jeden z ekspertów angielskich do spraw Polski niejaki Lewis Bernstein-Namierowski - późniejszy działacz syjonistyczny urodzony notabene w kraju nad Wisłą. Można zatem wysnuć wniosek, że niechęć europejskich kręgów liberalno-postępowych w połączeniu z brytyjską dewizą równowagi sił w Europie w pewnych obszarach utrudniały realizację szerokich rewindykacji postulowanych przez lidera endecji na konferencji pokojowej. Niewiele w tym względzie zmienił powrót do Paryża Paderewskiego i przyjęcie przez niego bardziej ugodowego stanowiska wobec Brytyjczyków²o.

Sprawa polska mogła jednak ciągle liczyć na poparcie Francji, chcącej za wszelką cenę osłabić powojenne Niemcy. 7 maja I9I9 roku w obecności 4 osobowej delegacji polskiej (Dmowski, Paderewski, Seyda, Kozicki) w wersalskim hotelu Trianon wręczono wysłannikom Berlina oficjalny projekt traktatu pokojowego z uwzględnieniem artykułów dotyczących Polski. Traktat w proponowanym brzmieniu nie do końca zadowalał Polaków. Ustanowienie Wolnego Miasta Gdańska, a także plebiscyty w okręgach kwidzyńskim i olsztyńskim stanowiły bowiem niebezpieczeństwo wzmocnienia niemieckich Prus Wschodnich. Niemniej Rzeczpospolita miała odzyskać niemal całe Poznańskie i Górny Śląsk. Dmowski doskonale zdawał sobie sprawę, że w panujących okolicznościach należy zaakceptować projektowaną linię graniczną z Niemcami ${ }^{21}$. Jego polityczna intuicja kolejny raz go nie zawiodła.

29 maja I9I9 roku delegacja niemiecka złożyła oficjalnie w Sekretariacie Generalnym Konferencji Pokojowej szereg uwag dotyczących przyszłej granicy z Polską. Niemcy zgadzały się na utworzenie niezależnego państwa polskiego, które będzie jednakże obejmowało jedynie

20 Zob. R. Dmowski, Polityka polska, dz. cyt., s. 373. Zob. też K. Kawalec, Roman Dmowski, dz. cyt., s. 338-339; S. Kozicki, Sprawa granic Polski..., dz. cyt., s. 68; J. L. Talmon, Namier (Bernstein-Namierowski), w: Encyclopaedia Judaica, v. I4, Detroit 2007, s. 770-77I.

2 I ADKPP, cz. 2: Granica polsko-niemiecka (dalej ADKPP:2), Paryż I925, s. 47-69. Zob. też S. Kozicki, Sprawa granic Polski..., dz. cyt., s. 69-72. 
ziemie zamieszkałe przez ludność bezsprzecznie polską. Podnosząc argument etnograficzny, Berlin podważał roszczenia Rzeczypospolitej do mniejszych lub większych części prowincji takich jak Prusy Wschodnie, Prusy Zachodnie, Poznańskie, Pomorze i Śląsk ${ }^{22}$.

Sytuacja stawała się poważna, tym bardziej że sam angielski preI3I mier Lloyd George nalegał na dokonanie ustępstw na rzecz Niemiec. Nie wróżyło to dobrze polskim interesom, ale delegacja reprezentująca w Paryżu Warszawę nie zamierzała przyglądać się biernie zmianie optyki niektórych mocarstw w sprawie powojennych granic. Już I czerwca zreferował dokładnie kwestię niemieckiego stanowiska, przewidując zagrożenie dla polskiej rewindykacji Górnego Śląska, Władysław Grabski. W konsekwencji 3 czerwca Polacy przesłali oficjalną notę do Sekretariatu Generalnego. Natomiast dzień później, wykorzystując swoje koneksje, Dmowski napisał list do premiera Francji Clemenceau z prośbą, aby delegaci polscy zostali jeszcze raz wysłuchani przed dniem odpowiedzi Niemcom. 5 czerwca wezwano przedstawicieli Polski na posiedzenie Rady Najwyższej. Pomimo oficjalnego oprotestowania mającego się odbyć plebiscytu na Górnym Śląsku dyplomaci wielkich mocarstw nie zamierzali tym razem ustępować argumentacji Polaków²3.

Choć nie udało się zrealizować wszystkich planów terytorialnych na odcinku granicy zachodniej, to pragmatyzm i realizm lidera endeków kazał mu przyjąć ostateczne efekty prac delegacji, którą kierował w Paryżu, z dużym zadowoleniem. Bez wątpienia symboliczną chwilą dla niego był moment, kiedy w Sali Lustrzanej słynnego Wersalu składał podpis pod traktatem przywracającym formalnie Rzeczpospolitą na mapę Europy.

Po latach napisze Dmowski o pamiętnym dniu 28 czerwca I9I9 roku:

Nigdy jak w owej sali, nie odczuwało się historycznej powagi chwili, dla nas, Polaków, poważniejszej, niż dla kogokolwiek. Na stole leżał tekst traktatu, który Niemcy mają podpisać, traktatu, który uznaje niepodległe państwo polskie,

22 ADKPP:2, S. 9I-IO7.

23 ADKPP:2, S. I09-I33, I35-I37, I45-I49; zob. też S. Kozicki, Sprawa granic Polski..., dz. cyt., s. 73-76. 
mocą którego Niemcy zwracają Polsce, nie wszystko wprawdzie co jej zagarnęli w przeszłości, ale prawie wszystko to, czego nie zdołali zniemczyć [...]. W ciągu swego wiekowego zmagania się z zachodnim sąsiadem nie miała Polska takiej chwili od Kazimierza Jagiellończyka, od drugiego pokoju toruńskiego. Zapomniałem wówczas o rzeczach i ludziach małych, o sporach i utarczkach codziennych, o marnych ambicjach i marnych intrygach, które stawały na drodze w dążeniu do wielkiego celu - myśl biegła po wielkich szlakach dziejowych, sięgała w odległą przeszłość, szukała odpowiedzi na zagadnienia przyszłego bytu państwa i narodu ${ }^{24}$.

Po podpisaniu traktatu z Niemcami najważniejszą sprawą stawała się kwestia wytyczenia granicy wschodniej. Tutaj również Dmowski musiał wykazać się niezwykłym kunsztem politycznym. Pomimo odrzucenia sił ukraińskich spod Lwowa i systematycznego wypierania ich w kierunku Zbrucza przez Armię gen. Hallera bezwzględnie koniecznym stawało się wygranie tej sprawy również na drodze dyplomacji. Lider endeków prowadził zatem podwójną grę - z oponentami politycznymi z obozu Piłsudskiego w kraju, gotowymi na dalekie ustępstwa względem Ukraińców, oraz z przedstawicielami wielkich mocarstw, obawiającymi się zbytniego wzrostu rangi Polski na arenie międzynarodowej. Galicja Wschodnia postulowana przez Radę Najwyższą miała uzyskać szeroką autonomię w ramach państwa polskiego. Toteż widząc nieustępliwość w tej sprawie przedstawicieli Anglosasów z Lloydem Georgem na czele, deklarował początkowo Dmowski na zewnątrz chęć przyznania Ukraińcom autonomii, ale równocześnie sprzeciwiał się misji pokojowej wojsk alianckich na tym obszarze, słusznie kalkulując, że może dojść do podziału tej dzielnicy25.

Na początku lipca I9ı9 roku Rada Najwyższa zakomunikowała Polakom, że statut autonomiczny Galicji Wschodniej i jej czasowa przynależność do Rzeczypospolitej są już przesądzone. Wobec tego Komisja do spraw polskich podjęła pracę zmierzającą do stworzenia formalnego statutu dla tej prowincji. Te decyzje odbiły się szerokim echem wśród polskiej opinii publicznej. Protestowali przeciwko nim

\footnotetext{
24 R. Dmowski, Polityka polska..., dz. cyt., s. 385.

25 Zob. K. Kawalec, Roman Dmowski, dz. cyt., s. 338-339; R. Wapiński, Roman Dmowski, dz. cyt., s. 277.
} 
w szczególności mieszkańcy rzeczonego terytorium, gdzie w wyniku ciężkich walk do końca lipca uporano się z ukraińską uzurpacją. Doszło nawet - na zaproszenie Dmowskiego - do spotkania przedstawicieli miasta Lwowa z członkami paryskiej Komisji 29 lipca. Niewiele ono jednak przyniosło. Wkrótce pojawił się kolejny problem - jakie terytorium ma obejmować Galicja autonomiczna. Na wniosek formalny przywódcy Narodowej Demokracji uzgodniono, iż autonomia będzie się zaczynać możliwie najdalej na wschód od Przemyśla. Był to sprytny zabieg, ale wobec "przecieków” płynących z Rady Najwyższej, że ta będzie stać nieugięta na straży granicy etnograficznej Dmowski wystosował w imieniu delegacji polskiej 25 sierpnia oficjalną notę do Prezesa Konferencji Pokojowej z żądaniem oddania Polsce Galicji Wschodniej bez zastrzeżeń ${ }^{26}$. Jak słusznie wskazywał w zakończeniu tego dokumentu: „Umowa, która nie uznałaby Galicji Wschodniej za część nierozdzielną państwa polskiego, pozwalająca jedynie Polsce zaprowadzić w tym kraju tymczasowe rządy cywilne, byłaby zachętą dla wszelkiego rodzaju agitacji i przeszkodą do jego pokojowego rozwoju" ${ }^{27}$.

Ratyfikowania bez warunkowej przynależności Galicji Wschodniej do Macierzy nie udało się już przeforsować Dmowskiemu osobiście na konferencji pokojowej, niemniej podwaliny do tego zostały wówczas uczynione. Ostatecznie dopiero Rada Ambasadorów I5 marca I923 roku uznała Galicję Wschodnią za integralną cześć Rzeczypospolitej $^{28}$. Dmowski tymczasem, zmożony ciężką chorobą płuc, przebywał jeszcze kilka miesięcy w Paryżu, ale jego stan zdrowia nie pozwalał na aktywne prowadzenie dyplomatycznej działalności. W połowie stycznia I920 roku, po namowie lekarzy, wyjechał na dłuższą kurację do Algieru'29.

W kontekście opisanych powyżej zmagań o granice nietaktem byłoby nie przytoczyć tutaj opinii o bohaterze tego referatu wypowiedzianej

\footnotetext{
26 Zob. S. Kozicki, Sprawa granic Polski..., dz. cyt., s. 8I-90.

27 ADKPP, cz. 3: Sprawa Galicji (dalej: ADKPP: 3), Paryż I926, s. 45.

28 "Gazeta Lwowska" I923 nr 62, s. ı; zob. też H. Batowski, Między dwiema wojnami..., dz. cyt., s. 6o-6r.

29 Zob. K. Kawalec, Roman Dmowski, dz. cyt., s. 352.
} 
przez znanego brytyjskiego dziennikarza i publicystę, dr. Emila Josepha Dillona, który śledził obrady kongresu. W swojej książce pod wymownym tytułem Konferencja pokojowa, w rozdziale Delegaci, tak pisał o liderze endecji:

Na ogół największym powodzeniem w bronieniu spraw cieszyli się prawnicy, chociaż jeden z delegatów mniejszych krajów, który zrobił największe wrażenie na przedstawicielach mocarstw większych nie należał do palestry. Kierownik delegacji polskiej Roman Dmowski, obrazowy, przekonujący mówca, zwięzły polemista i pomysłowy obrońca, któremu nigdy nie brakowało słów, porównania, argumentu ad hominem lub szybkiej i ciętej odpowiedzi, zjednał sobie arbitrów, pomimo że z początku zaliczali się do jego przeciwników - fakt znamienny, jeśli zważymy, że działo się to w zgromadzeniu, gdzie potężne wpływy sprzeciwiały się niektórym żądaniom zmartwychwstałej Polskiº ${ }^{\circ}$.

A jak oceniał swój wkład w dzieło odbudowy państwa polskiego sam zainteresowany? Można w tym miejscu przytoczyć ujmujące słowa z jego wystąpienia II czerwca I923 roku, kiedy to odbierał tytuł doktora honoris causa Wydziału Filozoficznego Uniwersytetu Poznańskiego za działalność polityczną, kulturalną i wychowawczą. Mówił wtedy w refleksyjnym tonie Dmowski:

Bóg mi dał to szczęście, że widzę inną Polskę, że umrę w innej niż ta zdeptana, zhańbiona i uciśniona, ze strachem w przyszłość patrząca, w której się urodziłem. Ale i wtedy, gdy ten obraz był daleki, nie czułem się nieszczęśliwy: swoją siłę moralną opierałem na poczuciu, że spełniam w miarę sił święty obowiązek, że wysiłki moje i tych, którzy na równi ze mną, pod tym samym nakazem i dla tego samego wielkiego celu pracują i walczą, lepszą niezawodnie zbliżają przyszłość, i na tej pewności, którą i dziś, więcej nawet niż ktokolwiek posiadam, że po nas przyjdą inni, którzy z tą samą wiarą, z tym samym przywiązaniem, z niemniejszym poczuciem obowiązku i odpowiedzialności pracą swoją będą Polskę dźwigali, walczyli o jej byt i o należne jej miejsce w świecie ${ }^{31}$.

Podsumowując działalność Dmowskiego na rzecz sprawy polskiej podczas konferencji pokojowej w Paryżu, możemy chyba pokusić się o stwierdzenie, że przez wiele wcześniejszych i kilka późniejszych

30 E. J. Dillon, Konferencja pokojowa w Paryżu 1919, Warszawa I92I, s. 52.

3 I Zob. Roman Dmowski 1864-1939. Życiorys..., s. I8. 
pokoleń, nie miała Rzeczpospolita tak skutecznego w wymiarze politycznym obrońcy swoich interesów. Wielka dyplomatyczna gra lidera endecji w Wersalu, okupiona przezeń samego zdrowiem, a i naznaczona stygmatem antysemityzmu nie tylko przez żywioły nieprzychylne Polsce, przyniosła jednak ostatecznie zamierzony efekt. Powrót państwa polskiego na mapę Europy w granicach bardzo zbliżonych do tych postulowanych przez przewodniczącego KNP stał się faktem. Można rzecz jasna dywagować, czy dałoby się ugrać więcej w bardziej sprzyjających okolicznościach, ale nie to jest przecież rolą historyków. Dmowski jak każdy człowiek miewał słabości i popełniał błędy, ale dzięki swojemu doskonałemu przygotowaniu intelektualnemu, niezwykłemu zmysłowi politycznego przewidywania i całkowitemu oddaniu sprawie, zdołał przekonać wielu możnych ówczesnego świata do słuszności polskich racji. Trudno w tym kontekście w ogóle wyobrazić sobie kształt terytorialny odrodzonej II RP bez pierwszoplanowej roli, jaką odegrał wówczas osiągając status prawdziwego męża stanu dr Roman Dmowski.

\section{BIBLIOGRAFIA}

I. ŹRÓDモA

\section{I.I. ŹRÓDŁA ARCHIWALNE}

Biblioteka Jagiellońska:

Kozicki, S., Pamiętnik Stanistawa Kozickiego 1876-1939, t. 3, cz. 6, [rękopis], BJ, sygn. rkp. 9784 III.

\section{I.2. ŹRÓDÆA DRUKOWANE}

Akty i dokumenty dotyczące sprawy granic Polski na Konferencji Pokojowej w Paryżu 1918-1919, cz. I: Program terytorialny Delegacji, zebr. i wyd. przez Sekretariat Generalny Delegacji Polskiej, Paryż i920. 
Akty i dokumenty dotyczace sprawy granic Polski na Konferencji Pokojowej w Paryżu 1918-1919, cz. 2: Granica polsko-niemiecka, zebr. i wyd. przez Sekretariat Generalny Delegacji Polskiej, Paryż I925.

Akty $i$ dokumenty dotyczace sprawy granic Polski na Konferencji Pokojowej w Paryżu 1918-1919, cz. 3: Sprawa Galicji, zebr. i wyd. przez Sekretariat Generalny Delegacji Polskiej, Paryż I926.

Komitet Narodowy Polski: protokoły posiedzeń 1917-1919, oprac. M. Jabłonowski, D. Cisowska-Hydzik, Warszawa 2007.

Dmowski, R., Polityka polska i odbudowanie państwa, Warszawa I925.

2. PRASA

"Gazeta Lwowska” I923 nr 62.

„Gazeta Warszawska” I9I9 nr I8.

\section{OPRACOWANIA I ARTYKUEY NAUKOWE}

Batowski, H., Między dwiema wojnami 1919-1939. Zarys historii dyplomatycznej, Kraków 200I.

Buszko, J., Od niewoli do niepodległości (1864-1918), t. 8: Wielka Historia Polski, Kraków 2000.

Dillon, E. J., Konferencja pokojowa w Paryżu 1919, Warszawa I92I.

Encyclopaedia Judaica, vol. I4, Detroit 2007.

Kawalec, K., Roman Dmowski, Poznań 2016.

Kozicki, S., Sprawa granic Polski na konferencji pokojowej w Paryżu, Warszawa I92I.

Lloyd George D., Prawda o traktacie wersalskim, t. I, Warszawa I939.

Pajewski J., Odbudowa państwa polskiego: 1914-1918, Warszawa I985.

Roman Dmowski 1864-1939. Życiorys - wspomnienia - zbiór fotografii, oprac. Feliks Fikus, Poznań I939. 
Wapiński, R., Roman Dmowski, Lublin I989.

Zamoyski, J., Powrót na mapę: Polski Komitet Narodowy w Paryżu 1914-1919, Warszawa I991. 


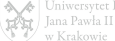

